\title{
Vitality of Complex Water Governance Systems: Condition and Evolution
}

Jurian Edelenbos, Ingmar van Meerkerk \& Corniel van Leeuwen

\section{Published, full reference:}

Edelenbos, J., Van Meerkerk, I., Van Leeuwen, C. (2015). Vitality of Complex Water Governance Systems: Condition and Evolution. Journal of Environmental Policy \& Planning, 17(2): 237-261. DOI: 10.1080/1523908X.2014.936584

Link to this article: Vitality of Complex Water Governance Systems: Condition and Evolution

\section{Author information}

All authors work at Erasmus University Rotterdam, Department of Public Administration, Research Group: Governance of Complex Systems, PO Box 1738, 3000 DR Rotterdam, The Netherlands.

Jurian Edelenbos is professor of Public Administration at the Erasmus University Rotterdam, The Netherlands, email: edelenbos@fsw.eur.nl.

Ingmar van Meerkerk is Post-doctoral researcher at the Department of Public Administration at the Erasmus University Rotterdam, The Netherlands, email: vanmeerkerk@fsw.eur.nl. Corniel van Leeuwen is Ph.D. student at the Department of Public Administration at the Erasmus University Rotterdam, The Netherlands, email: leeuwen@fsw.eur.nl.

\section{Abstract}

In this article the evolution of vitality of social systems in water governance processes, approached as social-ecological systems, is studied. Vitality as well as conditions for vitality are theorized and measured in two cases of the Dutch southwest Delta region. Different patterns and developments in the rise and fall of vitality are found in the two cases. We followed the developments of five conditions explaining the discovered changes in the levels of vitality throughout the years in the two cases. The first conclusion is that the conditions can be treated as clear enablers for increasing the level of vitality in both cases. Furthermore, a low score on (most of) the conditions are accompanied with low scores on vitality. The second conclusion that we can draw from our case comparative research deals with the relationship among the five conditions. We found two distinct types of relationships among the conditions: (1) a substituting, and (2) a mutually reinforcing relationship. The latter relationship is witnessed in 'big jumps in the level of vitality from low scores to high scores on vitality. The first relationship is discovered in certain phases of the cases, which maintain a certain high level of vitality.

Key words: vitality, conditions, water governance, social systems, trust, informal networks, case comparison 


\section{Introduction}

In contemporary literature on complex social-ecological systems, the need for adaptive capacity is stressed (e.g. Folke et al, 2005; Pahl-Wostl, 2007). It is argued that adaptive capacity is needed to deal with both the uncertainty of ecosystem dynamics as with the interdependencies resulting from social system's complexity (Pahl-Wostl, 2007; Van Meerkerk et al., 2013). This capacity of actors often pinpoints the quality of interaction among actors in the social system (Lubell and Edelenbos, 2013). Vitality is a concept that can be used to indicate the high quality interactions among actors (Healy, 1995; Horlings et al, 2009). Vital actor relationships provide the trustworthy context to explore and find new alternatives and solutions to complex issues (Folke et al, 2005). Vitality of social systems is a potentially interesting concept as is inhibits a double-meaning including both the explorative quality and the exploitative or productive quality of actor relationships, but needs more empirical grounding.

In this article, we want to dig deeper in the concept of vitality. We specifically aim to find conditions for vitality to emerge and increase. Different conditions are (implicitly) mentioned in the literature in this matter, such as trust, constructive dialogue and institutional cooperative arrangements (e.g. Healey, 1995; Horlings et al., 2009; Innes and Booher, 2004). Folke et al. (2005) and Huitema et al. (2009), reviewing the adaptive governance literature, stress the importance of participatory approaches, the sharing of information between actors, experimentation and learning of actors to adapt to changing circumstances and trustworthy actor relationships for dealing with complex social-ecological issues. However, empirical studies providing evidence-based insights in the relation between these conditions on the one hand and vitality on the other hand are very scarce. Our leading research question therefore is: which conditions can be considered important in developing and maintaining vitality of social systems in water governance practices?

In this article we try to provide empirical insights in this matter through conducting a comparative case study of water governance practices in the Netherlands. Water governance systems can be considered as complex social-ecological systems as many stakeholders (from governmental, societal and private sectors) with diverging interests and values deliberate and negotiate wicked, erratic and unpredictable issues (Teisman et al., 2009; Pahl-Wostl, 2007).

The article is structured as follows. In section 2 we build our theoretical framework and discuss the concept of vitality and conditions for vital social systems. In section 3 we discuss methodological issues and measurement of the main variables. Section 4 is devoted to empirical description and analysis of the two cases in subsequent order. In section 5 we compare insights gained from the two cases and draw several conclusions from this case comparison.

\section{Vital Actor Relations: Conceptual Framework}

\subsection{Water governance as social-ecological systems}

In this article we depict water governance systems as complex social-ecological systems (SES). This term emphasizes the integrated concept of humans in nature and stress that the delineation between social ecological systems is artificial and arbitrary. Social systems and ecological systems have reciprocal feedbacks and act as complex adaptive systems (Berkes 
and Folke, 1998; Folke et al, 2005). In fully understanding regional water governance systems one needs to understand the individual parts of social and ecological systems as well as their interplay and interdependency. Challenges in the water sector take place in multi-actor and governance settings in which many actors (private, public and societal) from different sectors (ecology, nature, agriculture, flood risk, etc.) and scales (local, regional and (trans)national) are involved (Edelenbos et al, 2013). The role and importance of vital actor relations is often stressed as an important condition to deal effectively, timely and legitimately with unpredictable and disruptive changes (Healey, 1995; Horlings et al., 2009; Innes and Booher, 2004).

\subsection{Vital social systems}

In the literature of SES many sources are mentioned that are considered important for adaptive (co)management, such as trust, informal networks, social learning, etc. (Folke et al, 2005). In our view these sources touch upon the vitality of social systems in order to cope with the uncertain and complex character of social-ecological systems. The aspects of trust and informal learning networks touch upon the relational qualities of social systems (Klijn et al, 2010). The relational capacity in social systems is considered important for adaptive and flexible responses to changes in ecological systems (Berkes and Folke, 1998).

Vitality in actor relationships is strongly related to the concept of governance capacity, and specifically relational capacity (Innes and Booher, 2003; Foster-Fishman et al, 2001). This form of capacity focuses on quality of the relations and interactions among involved actors. The literature on (governance) networks also stresses the importance of high-quality actor relationships. Vital systems are those social systems in which actors have productive interdependent relationships and in which actors frequently meet and exchange visions, meaning, interests, information and knowledge (cf. Sullivan \& Skelcher, 2002; Healey, 2006). Vital actor relations develop joint fact finding and mutual understanding of problem situations (Healey, 1995). Actor relations are not dominated by conflicts or deadlocks, but are characterized by ongoing interaction leading to joint strategies to solve problems. In other words, there is vital interaction which is lively, energizing and productive; it deals with the capacity to act (Horlings et al, 2009).

Vitality is a double-meaning concept that stresses both exploration (learning, reflexivity) and consolidation (productivity, exploitation) (Scharpf, 1999). Relationships in complex socio-ecological systems that are exclusively characterized by exploration, learning and reflexivity are not vital as they waste resources and are not consolidates in explicit results. The same holds for exclusive exploitation: this is not considered vital as it leads to routinized behavior and bureaucratized ways of working that don't meet the specific nature and situation of disruptive changes and extreme conditions (Scharpf, 1999; Folke et al, 2005).

Vitality of social systems concerns with the capacity of individuals to create both energizing and productive relations among actors and the quality of those actor relations (Horlings et al, 2009; Innes and Booher, 2003). Energizing means activating people to become part of interaction processes, while productive means that this energy is also consolidated in output and outcome (Innes and Booher, 2003). Vitality not only deals with the quality of the process of collaboration, but also with the quality of the content resulting from that process. It is then about consolidation of collaboration in joint agreements, common ground and (intermediate) (project) results. In this article we therefore define a vital system as "a social system of actors with different backgrounds and from different 
scales and levels with lively, energetic and productive relationships that are constantly seeking to explore, develop, and consolidate common ground in dealing with complex water governance issues".

Much literature in the field of for example network theory (cf. Koppenjan and Klijn, 2004) and complex governance systems (Teisman et al, 2009; Wagenaar, 2007) stress the importance of creating common perspectives, connecting different values and interest, as many complex spatial and water governance processes face the challenge of getting from fragmented to collective action. The coordination and combination of interests and values are seen as crucial in getting to collaboration and problem-solving processes (Healy, 2006).

Moreover, the common ground in dealing with water governance issues can be reflected by the degree to which different time orientations of involved actors have been synchronized to common time orientations (Zerubavel, 2003; Eshuis en van Buuren, 2013). This implies that short-term policy formulation and implementation needs constant reconsideration and alignment in the light of long-term expectations and future perspectives. It is also the other way around, long-term policy formulation needs reflection of the short-term developments in the policy field (c.f. Edelenbos et al, 2013). Vitality in this respect also reflects the way and the extent these different time orientations interact and got aligned.

\subsection{Conditions to increase vitality}

In the literature on social-ecological systems and complex (water) governance systems different conditions are considered and assumed important for the creation of vitality in these systems (Foster-Fishman et al, 2001; Folke et al, 2005). In this section we pay attention to several conditions that are mostly mentioned and discussed. We say beforehand that these conditions should not be approached isolated but as a configuration.

\section{Sense of urgency}

A common sense of urgency among actors in the actor network is considered important for vitality of governance networks (Kotter, 2008), as when actors feel the need for issues and problems they are more willing and committed to invest in active participation in the governance network and to reach effective and supported results (Edelenbos et al, 2010; Ostrom, 1998). Different forms of sense of urgency can be distinguished (Van Rooy, 2006). First there is policy (or top down) urgency: policy actors from different sectors see and feel the urgency of the issue. Second, one can distinguish bottom up urgency: all kind of stakeholders from society (NGOs, citizens, local stakeholders, etc.) feel the urgency to start self-organizing capacity in dealing with (local) issues. Vital networks are characterized by a mutually felt sense of urgency: policy urgency and bottom up urgency is felt and developed at the same time (Van Rooy, 2006). If one of the two is missing or lacking vitality will be out or reach, as there is no common feeling of the need to spend and to invest time, energy and other resources.

\section{Cross-boundary informal networks}

Vitality requires informal networks that transcend formal organizational structures and boundaries. Informal networks could enhance the vitality of social-ecological systems, because they can provide access to different kind of resources (or capital), for example information, financial resources and (legal) power (e.g. Granovetter, 1973; Folke et al., 
2005). Informal social networks refer to settings in which interaction is less structured by formal and detailed rules. Ashmos et al. (2000) argue that informal structures contributed to sharing of information between people. Furthermore, the informal character of the networks provides room for involved actors to think and behave outside their established roles and rules according to their formal position within established institutions. People are not directly pinned down to or held accountable for using certain statements. In this way informal meetings give more room for experimentation and exploration.

In informal networks, boundary spanning activities become important in building and activating relationships among different actors in the governance network (Van Meerkerk and Edelenbos, 2014). These boundary spanning activities activate actor relationships and in this way the exchange of information, knowledge, resources and perceptions. Especially face-to-face communication in these informal networks is considered crucial as it not only makes mutual alignment of strategies possible, but "...exchanging mutual commitment (...) creating and reinforcing norms, and developing a group identity appear to be the most important processes that make communication efficacious" (Ostrom, 1998: 7).

\section{Constructive dialogue}

Regarding the vitality of social systems, it is important to consider in what ways actors approach each other. A hostile and conflict-based approach will not be favorable for the development of vitality in actor networks, as communication and interaction will become minimal and based on fixed and formalized positions (Foster-Fishman et al, 2001; Healey, 2006; Innes and Booher, 2003). As is shown in governance network literature, hard-nosed bargaining will not lead to vitality in social systems. Instead, due deliberation, if it is organized properly, increases exchange of information, perceptions, and preferences, by which a learning process can take place and governance network performance could improve (Van Meerkerk et al., 2015). "The main reason is that arguing and reason-giving provide a mechanism to probe and challenge the normative validity of actors' interests as well as to check the empirical facts on which policy choices are based" (Risse and Kleine, 2007: 73-74).

The dialogue has to be 'open' or authentic: actors have to be "able to follow a discussion where it leads rather than be artificially constrained by rules about what can be discussed or what cannot be changed in the system, practice or law" (Innes and Booher, 2003: 38). This creates flexibility and the ability to mutual adjust to each other's points of view, interests and core values. Furthermore, it should be inclusive. In this way a variety of viewpoints, interests and values can be developed and communicated (Wagenaar, 2007). Moments of variation give individual actors the opportunity to put forward their own agenda.

\section{Trust}

Trust is recurrent aspect in the literature on social-ecological systems and adaptive governance (Adger et al, 2005; 2003; Folke et al, 2005). It is assumed that trust positively influences relation-building and the development of social capital in social systems and thus leads to vitality increase in social systems. Trusting another actor means that one is willing to assume an open and vulnerable position. One expects the other actor to refrain from opportunistic behavior even if the opportunity for it arises without having any guarantee that the other party will indeed act as expected (Deakin and Michie, 1997). Thus, the actor 
believes and expects that the other actor will take both actors' interests into account in the interaction (Rousseau et al., 1998).

Klijn et al (2010) distinguishes a number of aspects that together give shape to trust in complex social systems, of which two are used in this research: absence of opportunistic behavior and reliability. Trust may be defined as confidence in the reliability of a person or system, regarding a given set of outcomes or events (Sako, 1998). Reliability means that actors keep in mind the intentions of the other parties. The absence of opportunistic behavior is also considered a requirement for the development of trust among actors in the social system. Some authors argue that trust means that actors do not exploit other actors' vulnerability (Rousseau et al, 1998; Deakin and Wilkinson, 1998).

\section{Institutional cooperation arrangement}

Vital actor networks need certain formalization in an institutional embedding. An institutional arrangement is needed between partners to enhance and consolidate interaction and cooperation (Hodge and Greve, 2005). Institutional arrangements have different forms. It can be strictly formalized in arrangements like a steering committee, but can also be less formalized like alliances which function on a more ad hoc basis (Steijn et al, 2011). These rather low formalized institutional arrangements can be rather informal and can take the form of an informal project group, newly established consortiums or other hybrid organizational forms (Faulkner, 1995).

Apart from the exact level of formalization, institutional arrangements regulate the interaction between actors involved in the social system (March and Olson, 1989). According to Scharpf (1997:38) these institutions can be seen as "a system of rules that structure the courses of actions that a set of actors may choose". Institutional arrangements assure a certain stability and predictability in social behavior of and interactions between actors. Formalization via institutional arrangements assists the consolidation and productivity of vital actor relationships in the social system (Steijn et al, 2011).

\section{Methodology and measurement}

In our research a number of key variables can be distinguished, which set the conceptual and analytical framework in studying the two case studies Haringvliet and Grevelingen.

Below the main variables are listed, defined and operationalized:

Table 1: description and operationalization of the main variables in the research

\begin{tabular}{|c|c|c|c|}
\hline Main variables & Nature & Definition & Indicators \\
\hline Vitality & $\begin{array}{l}\text { Depended } \\
\text { variable }\end{array}$ & $\begin{array}{l}\text { A social system of actors with } \\
\text { different backgrounds and from } \\
\text { different scales and levels with } \\
\text { energetic and productive } \\
\text { relationships that are constantly } \\
\text { seeking both to explore and } \\
\text { consolidate common ground in } \\
\text { dealing with water governance } \\
\text { issues }\end{array}$ & $\begin{array}{ll}\text { - } & \text { Energetic: lively exploration of } \\
\text { perspectives, interests and values } \\
\text { - } \quad \text { Productive: consolidation } \\
\text { (exploitation) by finding common } \\
\text { ground reflected by a) aligned time } \\
\text { orientations, and b) aligned } \\
\text { interests and values across } \\
\text { governmental scales }\end{array}$ \\
\hline Sense of urgency & $\begin{array}{l}\text { Independent } \\
\text { variable }\end{array}$ & $\begin{array}{l}\text { The level of joint feeling of the } \\
\text { need of actors involved for } \\
\text { issues, problems and/or solutions }\end{array}$ & $\begin{array}{ll}- & \text { Presence of policy urgency } \\
- & \text { Presence of bottom up urgency }\end{array}$ \\
\hline Cross-boundary & Independent & Temporary ad hoc structures & Set up of multi-actor face to face, \\
\hline
\end{tabular}




\begin{tabular}{|c|c|c|c|c|}
\hline $\begin{array}{l}\text { informal } \\
\text { networks }\end{array}$ & variable & $\begin{array}{l}\text { that cross formal organizational } \\
\text { structures that are attended by } \\
\text { different actors with different } \\
\text { organizational backgrounds }\end{array}$ & & $\begin{array}{l}\text { informal meetings } \\
\text { Channeling frequent information } \\
\text { exchange organized by boundary } \\
\text { spanners }\end{array}$ \\
\hline $\begin{array}{l}\text { Constructive } \\
\text { dialogue }\end{array}$ & $\begin{array}{l}\text { Independent } \\
\text { variable }\end{array}$ & $\begin{array}{l}\text { A communication process } \\
\text { focused on the exchange of } \\
\text { information focused on } \\
\text { developing mutual understanding } \\
\text { (not based on fixed positions and } \\
\text { stands) }\end{array}$ & - & $\begin{array}{l}\text { Due deliberation among actors in } \\
\text { the system } \\
\text { Open and inclusive dialogue }\end{array}$ \\
\hline Trust & $\begin{array}{l}\text { Independent } \\
\text { variable }\end{array}$ & $\begin{array}{l}\text { A stable positive expectation that } \\
\text { actor A has (or predicts he has) of } \\
\text { the intentions and motives of } \\
\text { actor B in refraining from } \\
\text { opportunistic behavior, even if } \\
\text { the opportunity arises. }\end{array}$ & - & $\begin{array}{l}\text { Actors in the social system keep in } \\
\text { mind the intentions of the other } \\
\text { parties in finding solutions } \\
\text { Actors do not use the contributions } \\
\text { of other actors for their own } \\
\text { advantage }\end{array}$ \\
\hline $\begin{array}{l}\text { Institutional } \\
\text { cooperation } \\
\text { arrangement }\end{array}$ & $\begin{array}{l}\text { Independent } \\
\text { variable }\end{array}$ & $\begin{array}{l}\text { A set of formal rules and working } \\
\text { procedures that structure the } \\
\text { courses of action in a cooperation } \\
\text { process }\end{array}$ & - & $\begin{array}{l}\text { Presence of a joint working } \\
\text { structure, like project group, } \\
\text { steering group, etc. } \\
\text { The level that these rules are used } \\
\text { to structure the interaction process }\end{array}$ \\
\hline
\end{tabular}

The indicators were for each case scored on a Likert 5 point scale: each indicator was scored from 1 (low score) till 5 (high score). Each variable is measured by two indicators, leading to a summation ranging from 2 till 10 . We interpreted a score of 10 as double plus (++), 9-8 as a single plus (+), 7-5 as plus minus (+/-), 4-3 as single minus (-) and the score 2 as double minus (--). The scoring is done in a number of tables in order to provide a clear overview on the independent and depended variables. The scores are always substantiated in "explanatory words", as scoring doesn't always speak for itself. In this way the quantitative expression is always accompanied by qualitative clarification.

\subsection{Case selection}

The cases of Haringvliet and Grevelingen have been selected for the comparative case study research. One the one hand they are selected on the ground of similarity. Both cases:

- find their origin in the issue of (threatening) water quality;

- deal with a complex interrelated set of issues: water quality, water quantity, recreation, agriculture, and ecology and nature;

- $\quad$ are set at a regional scale (transcend local circumstances);

- represent a variety of actors with different interests, viewpoints and values, operating at different scales or governmental levels;

- represent the presence of different time orientations of actors, varying from the short to the long term;

- both are located in the South-Western part of Delta of the Netherlands.

Hence, in many ways these two cases are similar and therefore provide good starting conditions for exploring the meaning of conditions in creating vital social networks/systems. However, we also expect that there are considerable differences in both cases when it comes to the vitality of the governance system. The Haringvliet case - focused upon the decision to change the management of the sluices - is characterized by several implementation problems, partly due to conflicts between some local stakeholders and initiating regional and national governmental actors (Van Meerkerk et al., 2013; Kuijken, 
2010). The Grevelingen on the other hand is less characterized by conflict. In this case a renewal of the water system is discussed, bringing back the former estuarine dynamics to improve the water quality. A more constructive dialogue between stakeholders seems to exist in the Grevelingen.

We conducted theory-informed case studies in a focused way, to empirically analyse a particular theoretically relevant issue, vitality in social systems, and generate new theoretical knowledge from the empirical analysis. It comprises an instrumental case study, in which the researcher uses a specific case to gain more understanding about a particular phenomenon of interest (Stake 1995). The research design of two case studies does not enable us to develop generalized empirical knowledge but it does provide a detailed understanding of contextual and situational conditions that influence the evolution of vital social systems and the interplay between different conditions of vitality. We used the cases to test and to develop new insights (emerging from the cases) in finding explanatory conditions for vitality in regional water governance systems approached as complex socioecological systems.

\subsection{Methods used}

\section{Case Haringvliet}

At the time of writing, we have been following the Haringvliet case for about four years. All relevant written documents were subjected to detailed study, such as policy documents, memos, technical reports, and council minutes. Next, we conducted 20 semi-structured interviews with key stakeholders (national government, province, local government, water boards, NGOs, agriculture representatives). Firstly, the process and history of the cases were reconstructed. Secondly, questions were asked about the indicators mentioned in table 1. These interviews lasted about 1,5 hours on average, and the interview reports were checked and controlled by the respondents. Furthermore, we observed eight meetings between stakeholders and experts concerning the issue. These occasions were used to observe stakeholder interactions and to check our findings derived from the interviews and the document analysis.

\section{Case Grevelingen}

The case Grevelingen was qualitatively studied in two parts. The first 2 rounds were studied from a reconstructive perspective (Thomas, 2011). This was done merely by studying policy documents. Three additional interviews were held to enlighten several insights obtained from document analysis. The last two rounds (from 2010 on) were studied longitudinal with embedded research. One of the researchers observed around 30 meetings of the project organisations from 2010 onwards and was actively involved in several meetings as a secretary. These meetings consist of administrative meetings, project organization meetings and public conferences. Next to this, also in these rounds 9 interviews with key actors (national government, province, local government, water boards, NGOs, agriculture representatives) were held. At last a set of email messages and conversations were studied. In the last part of the research, the results were validated by reflections of members of the project organization. 
Both cases are reconstructed and analyzed in rounds (Teisman, 2000). Each round can be considered a case within the case of both Grevelingen and Haringvliet. For each case the rounds were scored for vitality and the conditions. Subsequently the rounds in each case were compared and changes in levels of vitality and conditions became apparent.

\section{Working process on analysis and scoring}

We want to explicitly report on the working process regarding the scoring and analysis of the cases. Two authors were distinct "case owners"; they were held responsible for retrieving data for their specific cases. They used secondary document analysis and interviewing as research methods for obtaining data on their case. The case owners, first, made a first draft case study description in which the main variables (figure 1) were analyzed, scored and explained. These drafts case study reports were then subjected to a joint process in which the three authors discussed the analysis and scoring of the two cases. In an open and reflexive discussion the scoring was questioned (by the two other authors) and explained by the case owners. The case owner provided the scores based on his case analysis. Then, the scores were discussed and the co-authors cross-read the cases in order to find out whether they would provide the same score to the variables. The goals of this joint and open discussion among the three researchers were to get a common understanding and use of the analytical framework and operationalized variables, and to perform a check on the way the case owner interpreted the case using and scoring the variables. We repeated this process in total 4 times during a time period of 5 months, in which we again and again elaborated, explained, and fine-tuned the case analysis and scoring of the variables. These meetings were highly important for making sure that the scores in both cases were based on a mutually shared framework for scoring. This process also improved the inter-rater reliability. This circular communication process led to case study reports which were rather lengthy and too long to be fully incorporated in the main text of this article. We worked rather focused in analyzing the two cases as our main goal was to compare the two cases. We didn't have the space to make lengthy in-depth single case study descriptions in the main text. We have always tried to fully substantiate the scoring on the variables in the consecutive rounds of the two cases by using case specific references and examples, and citations of respondents. However, we have also provided the full-length case descriptions in the appendix (which can be obtained online at the journal's website). This is done for making the case description and interpretation process as transparent as possible.

\section{Vitality in action: case analysis of Haringvliet and Grevelingen}

In this section we analyze both cases. First the case Haringvliet, and second the case Grevelingen is analyzed and scored on level of vitality and the distinguished conditions.

\subsection{Case introduction Haringvliet Sluices}

The Haringvliet sluices are one of the Dutch Delta Works which were built in reaction to the dramatic North Sea storm flood of 1953. The sluices, finished in 1971, closed off the estuary 
from the North Sea, leading to the disappearance of the estuarial tides and turning the Haringvliet into a fresh water basin. Although this was specifically beneficial for water safety, agriculture and fresh water supply in the area, the closing off has led to increasing sedimentation of suspended material and a damaging of estuarine ecological values and natural habitats (e.g. hindering the migration of fish). In line with the changing paradigm on water management (towards more Integrated Water Resources Management) and in reaction to the negative ecological and natural developments, the national water authorities (the ministry of Transport, Public Works and Water Management and the national governmental agency Rijkswaterstaat) developed a policy plan in order to restore the natural transition between river and sea in various steps. As a first step it was decided to open the Haringvliet sluices slightly (leave them ajar) during periods of high tides, allowing brackish North Sea water into the Haringvliet. Although this first step would not improve tidal dynamics, it was considered to be at least of direct value for enhancing the migration of fish, which served international agreements on this issue, codified in the Rhine Action Program. However, opening the sluices leads to a higher level of salinity, which has negative consequences for different users of the fresh water basin, such as farmers and water companies. Key stakeholders (e.g. water boards and drinking water companies) therefore raised significant objections concerning the risks of fresh water availability. We will focus our analysis on the moment national government formally decided to change the management of the sluices (in 2000). An important condition for implementation was that the intakes for water for drinking and agriculture should be relocated before the sluices could be opened (part of the so-called 'compensating measures'). In this way, the functionality of the freshwater intakes would be secured. To meet this condition, Rijkswaterstaat sought cooperation with the water boards and the province to develop freshwater canals.

\subsection{The evolution of vitality in different rounds}

Table 2 Scores on vitality in different rounds case Haringvliet

\begin{tabular}{|c|c|c|c|}
\hline Vitality scores & Round I (2000-2004) & Round II (2005-2010) & $\begin{array}{l}\text { Round III (2010-medio } \\
\text { 2013) }\end{array}$ \\
\hline $\begin{array}{l}\text { Energetic: lively } \\
\text { exploration of } \\
\text { perspectives, } \\
\text { interests and } \\
\text { values (1-5) }\end{array}$ & $\begin{array}{l}2 \text { (-) Partly exploration of } \\
\text { different land use functions } \\
\text { in the development of fresh } \\
\text { water canals, but } \\
\text { dominance of ecological } \\
\text { and natural values. }\end{array}$ & $\begin{array}{l}1 \text { (--) Focus of national and } \\
\text { provincial government on } \\
\text { implementation, also using } \\
\text { top-down planning } \\
\text { mechanisms. }\end{array}$ & $\begin{array}{l}3(+/-) \text { Reconsideration of } \\
\text { fresh water routes by the } \\
\text { province, together with } \\
\text { local stakeholders. Area } \\
\text { vision building of regional } \\
\text { stakeholders }\end{array}$ \\
\hline $\begin{array}{l}\text { Productive: } \\
\text { consolidation } \\
\text { (exploitation) by } \\
\text { finding common } \\
\text { ground (1-5) }\end{array}$ & $\begin{array}{l}2 \text { (-) Partly alignment } \\
\text { between national en } \\
\text { provincial government (in } \\
\text { interests and time } \\
\text { orientation). No alignment } \\
\text { with local government, } \\
\text { water boards and regional }\end{array}$ & $\begin{array}{l}1 \text { (--) No common ground } \\
\text { between the actors involved. } \\
\text { Increasing resistance of } \\
\text { regional stakeholders and } \\
\text { procedural conflicts between } \\
\text { governmental levels. }\end{array}$ & $\begin{array}{l}3(+/-) \text { Increasing common } \\
\text { ground among } \\
\text { governmental levels and } \\
\text { between stakeholders. } \\
\text { First steps in development } \\
\text { of business case }\end{array}$ \\
\hline
\end{tabular}




\begin{tabular}{|l|l|l|l|}
\hline & stakeholders. & & \\
\hline $\begin{array}{l}\text { Vitality total score } \\
(2-10)\end{array}$ & $\mathbf{4}(-)$ & $\mathbf{2 ( - )}$ & $\mathbf{6 ( + / - )}$ \\
\hline
\end{tabular}

In the first round we observe a low level of vitality. There is partly exploration and consolidation between national and provincial government, but no joint exploration and no or weak consolidation with regional key stakeholders: water boards, local governments, and local farmers, and water companies. The province and national government jointly explored the connection between a provincial project about nature development and the development of fresh water canals as part of the decision to change the management of the Haringvliet sluices. This exploration led to inclusion of some other land use functions, namely water retention, recreation, and nature development. National governmental interests with regard to realizing fish migration and tidal dynamics were strongly aligned with provincial interests in nature development (Interviews national government and province). This common ground is consolidated in an administrative agreement between national government and the province, in which the province gets full administrative responsibility for realizing the compensating measures. Furthermore, there is partly common ground in time orientation between national government (RWS) and the province as both are part of a joint policy orientation in which current and future water issues in the South West Delta are being addressed and being discussed. However, regional stakeholders and fresh water users are not part of this process. Next, the interests of regional stakeholders (water boards, municipalities, and local farmers) clashed with those of the province and of national government. As a respondent of the water board notes: "Despite of the compliant attitude of the water board [at the island Goeree Overflakkee], the water board always fostered some suspicion against the province. The interests of both parties are too different in this matter." The inclusion of agriculture and economic development, important for regional stakeholders, was avoided. As the manager of RWS notes: "We invested above all on reducing the concerns [of the key stakeholders]. [...] We did then not invested in a joint area vision where a part of their vision was included."

In the second round we observe increasing resistance of regional stakeholders and procedural conflicts between governmental levels. Due to increasing local resistance of farmers and inhabitants, the councils of local governments on Goeree-Overflakkee and Voorne Putten reject the nature development projects, which include the compensating measures for changing the management of the sluices. This illustrates a very low level of common ground. At the same time, the communication and cooperation between national government and the province decreased (Kuijken, 2010). In this round, national government is acting more on the back ground. For example, national government is not participating in the policy and decision-making process concerning the fresh water canals anymore (Interviews national government). In the same line, national government is less actively 
involved in the policy orientation process with regard to the future fresh water availability in the South West Delta. Interests beyond the regional and local level, such as the issue of climate change and its possible effects on the fresh water availability in the (mid-)long term are not included in this process, as the advice report of the Advisory Board for Rural Area also notes (RLG, 2008).

In the third round we observe joint exploration and increasing common ground, which is beginning to consolidate. At the end of 2009 the Province decided to reconsider the proposed fresh water canals, and to explore new fresh water routes together with local stakeholders. At Voorne Putten, an interaction process with many local and regional stakeholders was set up. There were frequent interactions, and the process aimed to develop a freshwater route, taking into account the regional stakes as much as possible. As one of the respondents of the local government notes: "the province is now more open for the input and perspective of local stakeholders". This resulted in a specific location and form of the freshwater route, which is accepted by local stakeholders, local government and the Water Board. At the island of Goeree-Overflakkee a more integrative area development is now being developed. Since 2011, the province, local government and non-governmental stakeholders (environmental interest organizations), with assistance of and in coordination with national government, are jointly working on an area vision. The fresh water route (the compensating measure for changing the management of the Haringvliet Sluices) is now coupled to an integrative area development, in which recreation and sustainable energy is included, which particularly serves regional interests. Consolidation of this common ground is reflected in the administrative agreement between the province and the local governments in 2012 and the development of a business case between public and private actors (specifically aimed at developing sustainable wind energy, but in relation with the integrative area development) (province South-Holland, 2013). The first steps are now taken in the preparation of the execution of this integrative area development project.

\subsection{The evolution of conditions of vitality in different rounds}

Table 3 Scores on conditions of vitality in different rounds case Haringvliet

\begin{tabular}{|c|l|l|l|}
\hline Conditions of Vitality & Round I (2000-2004) & Round II (2005-2010) & Round III (2010-present) \\
\hline$-\quad \begin{array}{l}\text { Presence of policy } \\
\text { urgency }\end{array}$ & $\begin{array}{l}4(+) \text { Top down policy } \\
\text { urgency, partly } \\
\text { connected with } \\
\text { provincial policy agenda }\end{array}$ & $\begin{array}{l}3(+/-) \text { Moderate top } \\
\text { down policy urgency, not } \\
\text { strongly expressed }\end{array}$ & $\begin{array}{l}\text { urgency, strongly } \\
\text { expressed towards the } \\
\text { region. }\end{array}$ \\
$-\begin{array}{l}\text { Presence of bottom } \\
\text { up urgency }\end{array}$ & $\begin{array}{l}1(--) \text { no bottom up } \\
\text { urgency }\end{array}$ & $\begin{array}{l}1 \text { (--) no bottom up } \\
\text { urgency }\end{array}$ & $\begin{array}{l}3 \text { (+/-) Bottom up } \\
\text { urgency regarding } \\
\text { integral area } \\
\text { development is } \\
\text { increasing }\end{array}$
\end{tabular}




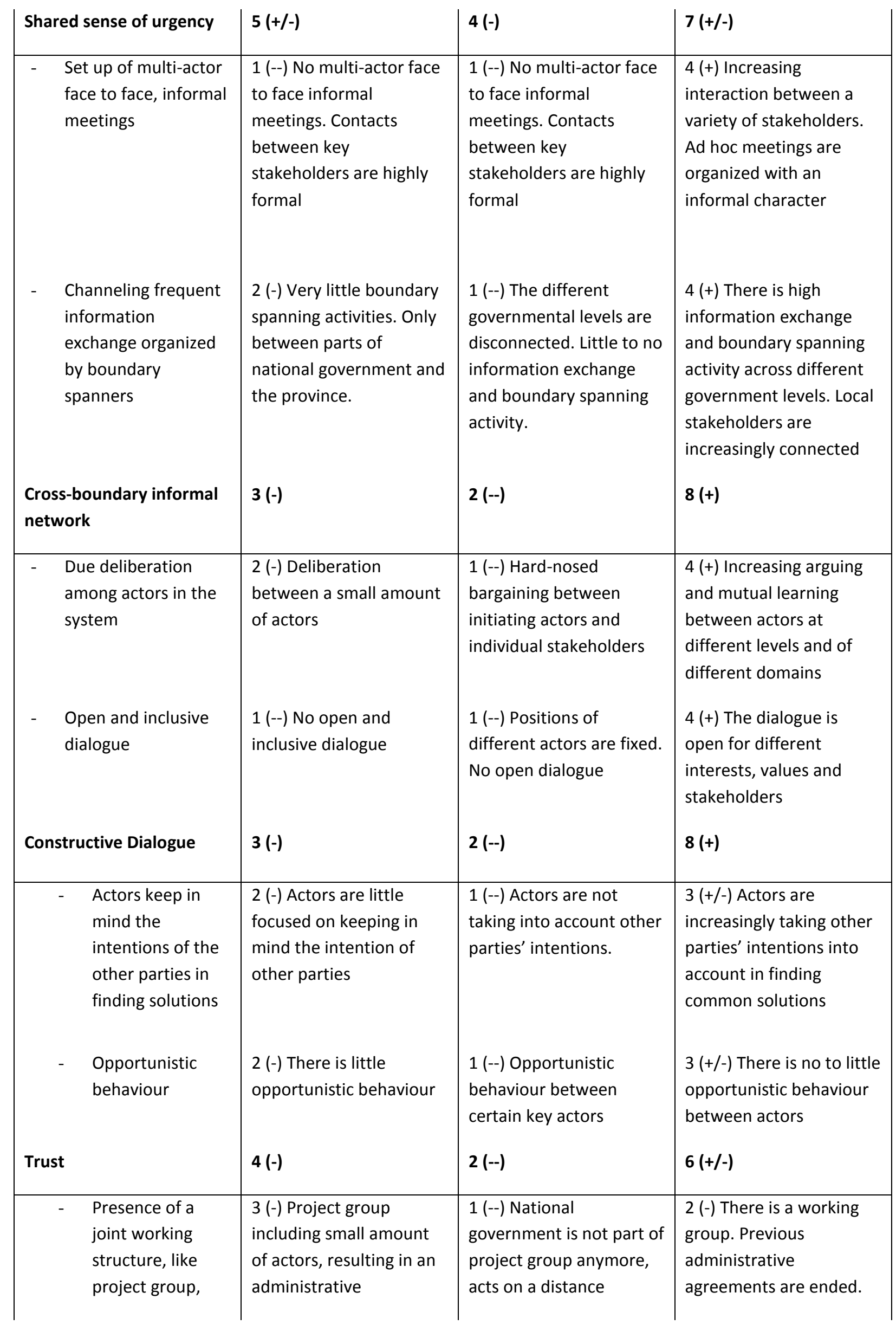




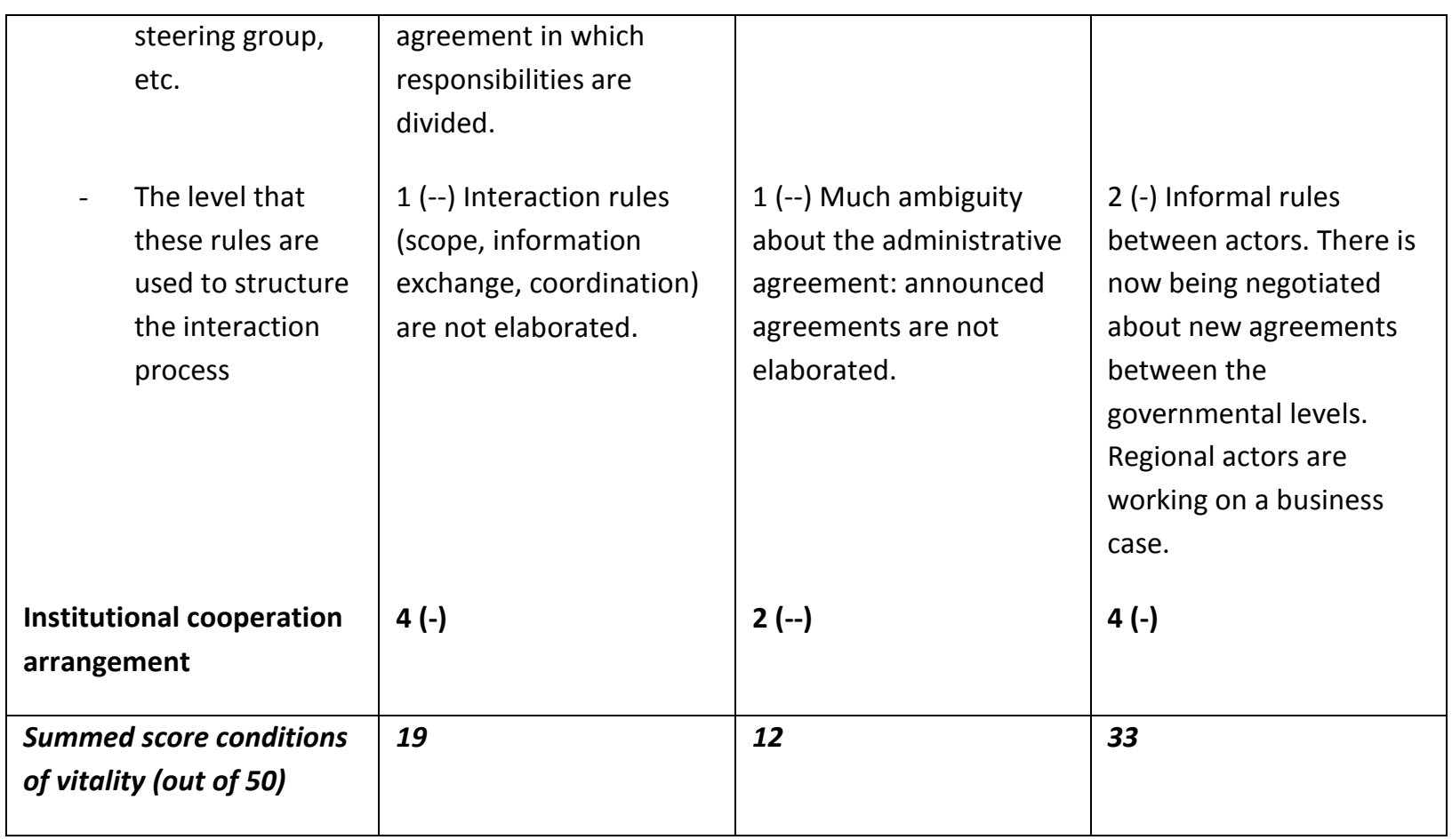

There is a big difference between the scores of the conditions of vitality in the first two rounds on the one hand and the third round on the other hand. All conditions score higher in the third round (with an exception of institutional cooperation arrangement). Comparing the second and third round cross-boundary informal network and constructive dialogue increase the most: both show an increase of 6 points. In the first and second round, the crossboundary interaction between the water boards, the local governments and the initiating actors (province and national government) is weak (cf. Kuijken, 2010). People within these organizations don't find each other easily. As one of the respondents of the Water board notes: "You miss the informal network. In previous times, you just called somebody from the department Water of the province if there was a problem..., and then you solved this jointly. Now, there are many people working who do not have that feeling for what is important for water boards." The contacts are mainly organized in the form of administrative meetings or via formal correspondence. As a respondent illustratively notes: "National government was not part of the Steering Committee Compensating Measures. We [policy department Water of national government] did not receive the administrative minutes or notes. [...] We were not aware of what was happening in the region." In the third round cross-boundary interaction is far more present. At different positions, new persons are active who are willing to cross boundaries and relatively easily know to find each other. Information exchange between different actors has strongly increased. National government is part of the Steering Committee again and is also present in the meetings with regional stakeholders. As a respondent of national government notes: "I have good contacts with [representative of local government]. I know to find her. [...] It is important that you also make the effort to go to the region. [...] That informal process...Are you receptive, and approachable? [...] Are you able to put yourself in the position of the region? I think that's important [...], these informal 
contacts are really important." Furthermore, face to face meetings between representatives of local government, regional stakeholders (environmental organizations), national government, and representatives of the agriculture community are organized in which connections between policy agendas are explored.

With regard to the condition constructive dialogue, the interaction between the managing actors (the initiators) and local/regional stakeholders was in the first two rounds mainly characterized by informing and sometimes consulting. There were no real attempts to include the diversity of interests in a mutually constructive way. Interactions were focused on reducing concerns instead of joint vision building. In the last round a more constructive dialogue emerged. On the island of Voorne Putten an interactive planning process between the province and local stakeholders was set up in which the location and form of the compensating measures were being discussed on the basis of arguing and mutually acceptance of the differences in interests at stake. As one of the managers of the province notes: "The group comes together every three weeks till the summer of 2010 [since March; a period of more or less five moths]. The actors are getting the feeling that they are serious listened to and they now really do have influence in the planning process." Also on the island of Goeree-Overflakkee a constructive dialogue between national government and local stakeholders took place around an integral area vision in which different interests across governmental scales are included.

In the last round trust between actors also increases substantially. The first two rounds are characterized by a low level of trust between the regional stakeholders on the one hand and the initiating actors - the province and RWS - on the other hand. Different respondents indicate that regional stakeholders do not think that the province and RWS really keep their interests in mind and vice versa. As one of the respondents of the Water Board notes: "The region had the feeling that its interests and input was not taken up seriously." When it comes to 'opportunistic behavior', different respondents note that actors mainly pursue their own agenda, which frustrates cooperation. For example, there are different conflicts between the province and the water board. Both actors blame each other for trying to "get more out of [the administrative agreement] than there is in it. You jointly decide to buy a bike, but along the way it turns out to be a Ferrari." as one respondent illustratively notes. In the last round, the level of trust between local stakeholders, the province, and national government starts to increase. According to the respondents, they now have the feeling that their interests are taken up more seriously and that the managing actors are far more prepared to look for connections with the local policy agendas.

In the first two rounds there are two administrative agreements: between national government and the Province and between the province and the water board. However, rules about information exchange, scoping, and decision rules remained implicit. Cooperation or coordination mechanisms were not developed. This caused different perceptions about which principles were leading (e.g. with regard to the needed budget and 
the necessity of dike improvements). An evaluation report of national government notes the following about the administrative agreements in the second round: "Many times agreements remained implicit or where pushed forward. For example, in both the administrative agreements between the national government and the province (in 2004) as between the province and the water board (in 2006), it was stated that certain specific agreements had to be made in advance. However, this did not happened..." (Kuijken, 2010: 8). In the last round regional and national governmental actors are jointly, together with the responsible private actors for drinking water, developing new administrative arrangement in which coordination and cooperation, as well as financial responsibilities and risks, are elaborated.

\subsection{Confronting level of vitality with conditions of vitality}

There is a low level of vitality in the first two rounds, especially in the second round. Overall, we observe the same pattern with regard to the conditions of vitality (they have a low score in the first round and these scores further decrease in the second round). Vitality reaches a moderate level in the third round. Most of the conditions score much better in this third round. When we compare the second and third round we see that they all increased. Regarding the relationship between the various conditions: it is interesting to see that, coming from a low level of vitality, things are beginning to change with different persons being active in the network (or some people taking a different role). These people have been conducting more boundary spanning work than was done in the previous rounds. This boundary spanning work is strongly related with a constructive dialogue taking place between the various actors and these two conditions seem to catalyze trust between the various actors. The different actors seek to find appropriate institutional cooperation arrangements now. This is now being developed, but it seemed to be important to first build trust between the various actors.

\subsection{Case introduction Grevelingen}

As a reaction on the major flooding disasters in 1906 and 1953 in the Southwest part of the Netherlands, the national government executed some major interventions in the water defense system (De Schipper, 2008; Slager, 2010). As a result of these interventions, which are known as the 'Delta works', the Southwest Delta with its characterizing estuarine dynamics transformed in several lakes losing its dynamics and connection with the North Sea, which causes several ecological problems. One of the lakes in which the ecological problems are prevalent is the lake Grevelingen. The lake Grevelingen is a salt water basin, because of a little culvert in the Brouwersdam (created in 1978), connecting it with the North Sea. However, this culvert proved not to be enough for providing the lake Grevelingen with enough oxygen. This led to deterioration of the water quality. In 2006, the national water authority started an exploration on the consequences of reintroducing estuarine dynamic in the lake Grevelingen. In subsequent years, more studies followed but an ultimate solution never has been implemented. 


\subsection{The evolution of vitality in different rounds}

Table 4 Scores on vitality in different rounds case Grevelingen

\begin{tabular}{|c|c|c|c|c|}
\hline Vitality scores & $\begin{array}{l}\text { Round I (2005- } \\
2006)\end{array}$ & $\begin{array}{l}\text { Round II (2006- } \\
\text { 2009) }\end{array}$ & $\begin{array}{l}\text { Round III (2009- } \\
\text { 2012) }\end{array}$ & $\begin{array}{l}\text { Round IV (2012-mid- } \\
\text { 2013) }\end{array}$ \\
\hline $\begin{array}{l}\text { Energetic: lively } \\
\text { exploration of } \\
\text { perspectives, } \\
\text { interests and } \\
\text { values (1-5) }\end{array}$ & $\begin{array}{l}5(++) \text { Much } \\
\text { exploration of } \\
\text { economical en } \\
\text { nature } \\
\text { perspectives }\end{array}$ & $\begin{array}{l}3(+/-) \text { Average } \\
\text { exploration only in } \\
\text { inner circle }\end{array}$ & $\begin{array}{l}5(++) \text { High degree of } \\
\text { exploration by broad } \\
\text { network of actors }\end{array}$ & $\begin{array}{l}5(++) \text { High degree of } \\
\text { exploration by broad } \\
\text { network of actors }\end{array}$ \\
\hline $\begin{array}{l}\text { Productive: } \\
\text { consolidation } \\
\text { (exploitation) } \\
\text { by finding } \\
\text { common } \\
\text { ground (1-5) }\end{array}$ & $\begin{array}{l}3(+/-) \text { average } \\
\text { consolidation. Only } \\
\text { partly alignment of } \\
\text { interests. }\end{array}$ & $\begin{array}{l}4(+) \text { above average } \\
\text { consolidation } \\
\text { shown by integral } \\
\text { vision. Only partly } \\
\text { alignment for time } \\
\text { orientation }\end{array}$ & $\begin{array}{l}5(++) \text { high } \\
\text { consolidation } \\
\text { illustrated by } \\
\text { common ground } \\
\text { (interests and time } \\
\text { orientations) }\end{array}$ & $\begin{array}{l}5(++) \text { high degree of } \\
\text { consolidation } \\
\text { illustrated by } \\
\text { common ground } \\
\text { (interests and time } \\
\text { orientations) }\end{array}$ \\
\hline $\begin{array}{l}\text { Vitality total } \\
\text { score }(2-10)\end{array}$ & $8(+)$ & $7(+/-)$ & $10(++)$ & $10(++)$ \\
\hline
\end{tabular}

The Grevelingen proved to be a case with high level of vitality although the level varied during the different decision rounds studied. Formal moments of consolidation played a crucial role to revitalize the network. Lively moments of exploration were interspersed with moments of consolidation. In the first round, the level of vitality in the case Grevelingen was high. The first round started with a broad deliberation (in townhouses) in 2005 with lively interaction about the future of the lake in which all actors had the possibility to participate. The network was full of energy and perspectives, interests and values were actively explored. The broad deliberation led to an awareness of the issues in the lake Grevelingen. Other part of a vital governance network is the consolidation. In this round we see an active search to find common ground by working on a joint vision for the lake. Nevertheless, in this phase the Nature and Recreation Authority is not fully able to consolidate this common ground (no concrete projects and ratified vision). In the spring of 2006 a first version of the integral vision was presented to stakeholders but it took until 2007 to determine the integral vision. In this phase we see roughly aligned interests and values but only partly aligned time orientations. There were actors with more short time orientations (merely entrepreneurs) while the national water authority preferred a rather long term orientation.

In the second round the level of vitality is a little bit lower (average). The earlier mentioned deliberation round in this round resulted in an integral vision (ratified by 17 organizations). Common ground related to interest and values was consolidated. This also resulted in the elaboration of concrete projects. The vision however is less clear in its time orientation. No clear point on the horizon is formulated and no time schedule is written down. Time horizons of actors have not been aligned so far. After determining the vision, interaction on the scale of the basin became more irregularly. The problems related to the water quality were not included in spatial developments, but were studied apart in a SNIP- 
study carried out by the National Water Authority (start in 2006). Outcomes of the study were only shared occasionally in conferences. The years 2007 and 2008 were marked by exploration of the water quality issues in the SNIP-study and exploration of concrete projects related to economic issues. The interaction became less intensive for the broad circle of stakeholders. However, at the inner core (project team) the communication around the water quality issue was augmenting. In 2009 the results of the SNIP-exploration were officially presented. The conclusions led to more consolidation of interests and values (a common project-document). In sum, the vitality in this period proved to be average (average exploration, above average consolidation).

In the third round the level of vitality is very high (both exploration and consolidation augmented). By the start of the MIRT-exploration (follow-up of the SNIP-study) lively exploration of perspectives, interests and values took place. Like the project manager said: "Integrality was the magic word". The exploration did not stop further on in the MIRTexploration. The project organization internalized water safety issues in the project (using the Grevelingen for water storage). Moreover, two times a year the project organization organized well attended (200 attendees) Grevelingen conferences in which the broad debate about the future of the Grevelingen was facilitated. In this round we also see moments of consolidation. The first moment was with the presentation of the starting document of the MIRT-exploration. In this document the project organization consolidated the previously developed common ground. "Ecology, economy and safety needed as much as possible to be combined in the solutions", was the explicit mission of the steering committee (NRA, 2010). A second moment of consolidation can be seen in the internalization of the water safety issue into the project. Finding solutions for water storage became one of the project goals of the MIRT-exploration. Thereby the Grevelingen was seen within the larger picture of the Southwest Delta. At the end of the MIRT-exploration the vitality was put to the proof. The commonly developed grounds in terms of interests, values and time orientations were frustrated by the lack of money to bring measures to implementation. However, this lack of money did not bring the governance network into inertia. By combining the planning studies of the lake Volkerak Zoom and the lake Grevelingen in a national planning document, consolidation of the developed common ground took place. Time orientations were mitigated. Time horizons for implementation constrainedly had to be stretched. The postponing of the proposed measures did not lead to unhooking of actors in the governance network.

In the fourth round the level of vitality is also very high with lively exploration of perspectives, interests and values. Like one of our respondents said: 'It seems that we are doing all explorations anew, just to buy time for decision making'. This was for example true for the studies to use the lake Grevelingen for water storage. Because of the synergetic benefits this possibility was further studied. Like in the former round, the level of consolidation is also very high. The possibility of water storage in the Grevelingen in the future was consolidated in the national Delta program 2013 and 2014 (national policy document). Next to this, in the spring of 2013 the project team of the National Planning Document started an intensive deliberation process with several stakeholders to find solid and supported decision information. This took place through a series of workshops in which all alternatives for both lakes were studied and rated. The results of this interactive process were included in both the starting document of the National Planning document and further studies. It is both a form of exploration and consolidation. Furthermore on June $6^{\text {th }} 2013$ a 
strategic consultation with the minister of Public works was used to consolidate the developed common ground. The different time orientations of public and private actors in this round were more and more aligned.

\subsection{The evolution of conditions in different rounds}

The in the former paragraph described level of vitality stands not on its self but was accompanied by the presence of several conditions. In this section the conditions for a vital governance network are empirically discussed. We do this by focusing on two central elements:

- The overall conditional scores

- The development of two striking conditional scores

Table 5 Scores on conditions of vitality in different rounds case Grevelingen

\begin{tabular}{|c|c|c|c|c|}
\hline $\begin{array}{l}\text { Conditions of } \\
\text { Vitality }\end{array}$ & $\begin{array}{l}\text { Round I (2005- } \\
2006)\end{array}$ & $\begin{array}{l}\text { Round II (2006- } \\
\text { 2009) }\end{array}$ & $\begin{array}{l}\text { Round III (2009- } \\
2012)\end{array}$ & $\begin{array}{l}\text { Round IV (2012- } \\
\text { mid 2013) }\end{array}$ \\
\hline 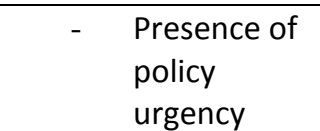 & $\begin{array}{l}1 \text { (--) No top down } \\
\text { policy urgency }\end{array}$ & $\begin{array}{l}2(-) \text { Low degree of } \\
\text { top down policy } \\
\text { urgency }\end{array}$ & $\begin{array}{l}3(+/-) \text { Average top } \\
\text { down policy } \\
\text { urgency }\end{array}$ & $\begin{array}{l}3 \text { (+/-)Average top } \\
\text { down policy } \\
\text { urgency }\end{array}$ \\
\hline 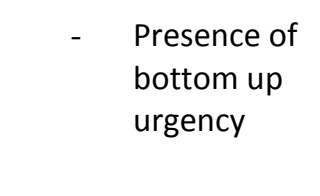 & $\begin{array}{l}3(+/-) \text { Average } \\
\text { degree of bottom } \\
\text { up urgency }\end{array}$ & $\begin{array}{l}5(++) \text { Very high } \\
\text { degree of bottom } \\
\text { up urgency }\end{array}$ & $\begin{array}{l}5(++) \text { Very high } \\
\text { degree of bottom } \\
\text { up urgency }\end{array}$ & $\begin{array}{l}5(++) \text { Very high } \\
\text { degree of bottom } \\
\text { up urgency }\end{array}$ \\
\hline Sense of urgency & $4(-)$ & $7(+/-)$ & $8(+)$ & $8(+)$ \\
\hline 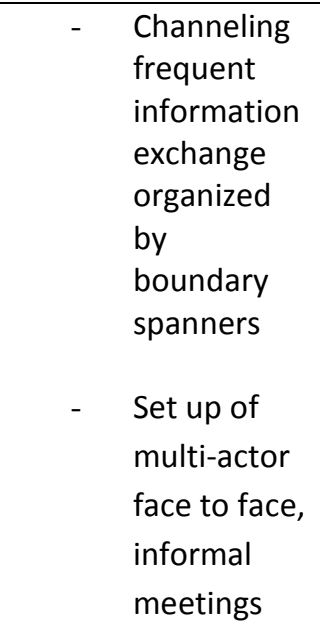 & $\begin{array}{l}5(++) \text { Very much } \\
\text { information } \\
\text { exchange } \\
5(++) \text { Informal face } \\
\text { to face meetings }\end{array}$ & $\begin{array}{l}2(-) \text { Barely } \\
\text { information } \\
\text { exchange in broad } \\
\text { network } \\
3(+/-) \text { ad hoc } \\
\text { informal meetings } \\
\text { in inner circle }\end{array}$ & $\begin{array}{l}5(++) \text { Informal } \\
\text { multi-actor } \\
\text { meetings to share } \\
\text { MIRT-results and } \\
\text { initiate projects }\end{array}$ & $\begin{array}{l}5(++) \text { Frequent } \\
\text { information } \\
\text { exchange }\end{array}$ \\
\hline
\end{tabular}




\begin{tabular}{|c|c|c|c|c|}
\hline $\begin{array}{l}\text { Cross-boundary } \\
\text { informal network }\end{array}$ & $10(++)$ & $5(+/-)$ & $10(++)$ & $10(++)$ \\
\hline 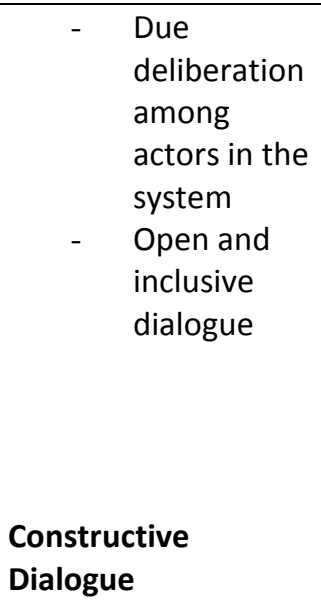 & $\begin{array}{l}4(+) \text { Due } \\
\text { deliberation } \\
5 \text { (++) Open and } \\
\text { inclusive dialogue } \\
9 \text { (+) }\end{array}$ & $\begin{array}{l}3 \text { (+/-) Average due } \\
\text { deliberation } \\
4 \text { (+)More bilateral } \\
\text { negotiations, open } \\
\text { dialogue between a } \\
\text { few organizations } \\
7 \text { (+/-) }\end{array}$ & $\begin{array}{l}4(+) \text { Due } \\
\text { deliberation } \\
5 \text { (++) Open and } \\
\text { inclusive dialogue } \\
\text { within project goals } \\
\mathbf{9 ( + )}\end{array}$ & $\begin{array}{l}5(++) \text { Open and } \\
\text { inclusive dialogue } \\
\text { within project goals } \\
10(++)\end{array}$ \\
\hline $\begin{array}{l}\text { - Actors keep } \\
\text { in mind the } \\
\text { intentions } \\
\text { of the other } \\
\text { parties in } \\
\text { finding } \\
\text { solutions }\end{array}$ & $\begin{array}{l}2(-) \text { Actors do not } \\
\text { know each other } \\
\text { well } \\
4(+) \text { No signs } \\
\text { opportunistic } \\
\text { behaviour } \\
6 \text { (+/-) }\end{array}$ & $\begin{array}{l}4(+) \text { Intentions of } \\
\text { other actors are } \\
\text { taken into account } \\
5(++) \text { No } \\
\text { opportunistic } \\
\text { behaviour } \\
9(+)\end{array}$ & $\begin{array}{l}5(++) \text { Very high. } \\
\text { Intentions of others } \\
\text { are fully taken into } \\
\text { account } \\
5 \text { (++) No } \\
\text { opportunism }\end{array}$ & $\begin{array}{l}4(+) \text { Level of trust } \\
\text { is ok, but duration } \\
\text { of process leads to } \\
\text { little decrease of } \\
\text { trust } \\
4(+) \text { Hardly } \\
\text { opportunism }\end{array}$ \\
\hline 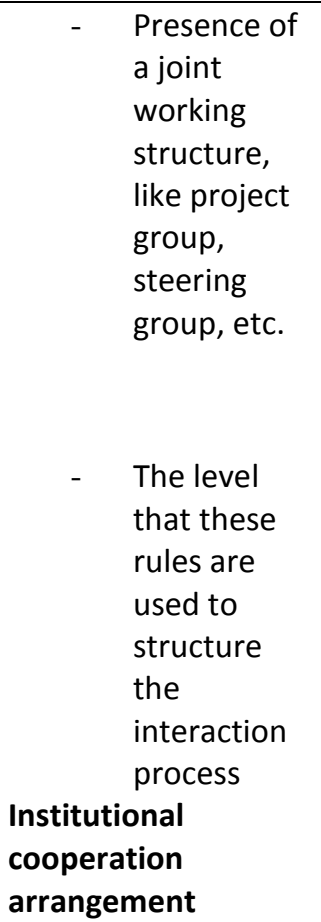 & $\begin{array}{l}4(+) \text { Cooperation } \\
\text { between primarily } \\
\text { regional } \\
\text { stakeholders in } \\
\text { NRA } \\
3(+/-) \text { Interaction } \\
\text { rules are used but } \\
\text { ad hoc }\end{array}$ & $\begin{array}{l}4(+) \text { Cooperation } \\
\text { between primarily } \\
\text { regional } \\
\text { stakeholders in } \\
\text { Nature and } \\
\text { Recreation } \\
\text { authority } \\
4(+) \text { functioning } \\
\text { Grevelingen } \\
\text { alliance }\end{array}$ & $\begin{array}{l}5 \text { (++) Cooperation } \\
\text { in Steering } \\
\text { committee } \\
\text { Grevelingen, } \\
\text { Steering } \\
\text { Committee } \\
\text { Southwest delta, } \\
\\
5 \text { (++) Structured } \\
\text { working process }\end{array}$ & $\begin{array}{l}5(++) \text { Steering } \\
\text { committee } \\
\text { Southwest Delta, } \\
\text { Project teams } \\
\text { regional economic } \\
\text { program }\end{array}$ \\
\hline
\end{tabular}




\begin{tabular}{|l|l|l|l|l|}
\hline $\begin{array}{l}\text { Summed score } \\
\text { conditions of vitality } \\
\text { (out of 50) }\end{array}$ & 36 & 36 & 47 & 46 \\
\hline
\end{tabular}

Overall, the case Grevelingen scores high on the different conditions of vitality. In the first two rounds the summed score of the conditions is 36 of a maximum of 50 . There are only a few striking low scores, the sense of urgency in the first round (4) and the cross boundary informal network (5) in the second round. In the third round we see a boost in the overall score, 47 of a maximum of 50 . From the second to the third round, every single condition has a higher score. The increase is especially caused by a large increase of cross-boundary informal network and a moderate increase of constructive dialogue and institutional cooperation arrangement. In the fourth round the scores merely stabilize (overall score of 46), except a little decrease in trust.

When we have a closer look on the above presented scores on the different conditions, the first striking condition is the sense of urgency. The sense of urgency consists of two indicators, respectively the presence of policy urgency and, secondly the presence of bottom up urgency. In the first decision round the sense of urgency is relatively low. Due to a broad deliberation process started in 2005 the bottom up urgency started to grow. Like the project manager said: "We went evening to evening to town houses to talk with stakeholders and local residents". However, there was no top down policy urgency for the issues. The average bottom-up urgency (developed in the first round) grew out to a high degree of bottom-up urgency in the second round. This can be seen in the fact that regional governments lobbied for a study of the water quality in the lake Grevelingen. The top down policy urgency was still low. Like one of our respondents said: "Until 2027 the national government is not tied to do something in the Grevelingen".

In the third round, we see a shift in the sense of urgency which is high due to the very high bottom up urgency and an average level of top down policy urgency. The Grevelingen from that moment was seen as a possibility for water storage, an issue with high policy urgency in the Netherlands. In the fourth round the sense of urgency was also high (water safety urgency).

The second striking condition is cross-boundary informal networks.. In the first round the cross-boundary informal network condition scored very high. There was very much information exchange initiated by boundary spanners and there were frequent face to face informal meetings with the goal to "set an agenda for the Grevelingen" (Projectmanager). In the second round we see a drop in this conditional score to average. Informal multi-actor face to face meetings became scarcer and information exchange in a broad network on the scale of the basin was barely initiated. More bilateral interaction patterns occurred around concrete projects and the SNIP-exploration was a "more internal governmental study" (National water authority). In the third round the condition scored very high. The MIRTexploration was much more public orientated with frequent information exchange and face to face informal meetings (Grevelingen conferences). This was continued in the fourth round. 


\subsection{Confronting level of vitality with conditions of vitality}

The Grevelingen (although the level varied) proved to be a case with a high level of vitality. During the last two decision rounds the level of vitality reached its highest point when aligned time orientations and aligned interests and values got illustrated in joint visions and concrete plans. When we confront the level of vitality with the conditions of vitality, we are able to deduct some conclusions. Where the degree of vitality proved to be relative stable in time, the conditions proved to be more fluctuating in time. There is however a big correlation between the overall level of vitality and the summed score of conditions of vitality in every decision making round. This leads to the preliminary conclusion that the identified conditions highly explain the level of vitality in governance networks. Furthermore we can conclude that the conditions of vitality seem to be reversible in vital networks. Let us have a closer look on this conclusion. In the first round we see a low level of the sense of urgency and we see a very high level of cross boundary informal network while in the second round we see an average sense of urgency and an average level of cross boundary informal network. The augmented sense of urgency intercepted the drop of the cross boundary informal network in the summed score. Moreover we see an augmenting level of trust in the first three rounds of the decision making process while the constructive dialogue is decreasing. Higher levels of trust seem to make due deliberation and open and inclusive dialogue less necessary. It is not easy to say which conditions were decisive but the role of formal cooperation structures in combination with a shared bottom-up sense of urgency and a lot of boundary spanning activities seem to be very important to keep the governance network vital. A last observation is the influence of new people in the governance network. New people bring new energy and new views which stimulate lively exploration of perspectives, interest and values.

In the concluding section we compare the results from the two in-depth case studies and draw conclusion from this case comparison.

\section{Conclusions drawn from case comparative analysis}

In this article our goal was to find the conditions that can be considered important in developing and maintaining vitality of social systems in water governance practices. We elaborated five conditions, i.e. (1) sense of urgency, (2) cross-boundary informal network, (3) constructive dialogue, (4) trust, and (5) institutional arrangements; these five conditions are frequently discussed and recurring themes in literature on social-ecological systems, (water) governance, and network theory. We then conducted a comparative qualitative case study research in which we dealt with two Dutch (water governance) cases: Haringvliet Sluices and Grevelingen; both cases are located in the southwestern delta region of the Netherlands.

This comparative case study research delivers us a couple of insights in the interrelationship between on the one hand the conditions and on the other hand vitality of social systems in water governance practices. We are able to draw two distinct conclusions from our case comparative research. The first conclusion is that the conditions can be treated as clear enablers and triggers for increasing the level of vitality in social systems in water governance practices; the identified conditions highly explain the level of vitality. In 
both cases a low score on (most of) the conditions are accompanied with low scores on vitality. The case Haringvliet Sluices is the illustrative case in this respect, as this case overall scores relatively low on both during most rounds of decision-making. However, it also the other way around: high scores on (most of) the conditions are also accompanied with high scores on the level of vitality. The second case, Grevelingen, is a clear illustration of this pattern as this case is overall more positive on the level of vitality in the social systems of the water governance practice. The level of the conditions and the level of vitality can be considered communicating vessels, as the observed upward changes in the level of vitality during the rounds of decision-making were accompanied with upward changes in the level of the conditions. The case Grevelingen for example shows us that the upward change of vitality during round 3 of the decision-making process (from a score of 7 to 10) coincides with a 'jump' in positive scores of all five conditions. We can observe a similar pattern in the case of Haringvliet Sluices where vitality increases during rounds 2 and 3 (from a score 2 to 6 in the third round). This increase in vitality also coincides with an increase in the scores on the conditions. Vitality can therefore also be considered a dynamic concept that can develop during the process of decision-making under the influence of the five distinguished conditions.

The second conclusion that we can draw from our case comparative research deals with the relationship among the five distinguished conditions. We found two distinct type of relationships among the conditions: (1) a substituting, and (2) a mutually reinforcing relationship. In the first relationship, all conditions do not have the same (positive or negative) score in the same round of decision-making. Some negative scores on conditions are substituted (in the meaning of "compensated") by positive scores on other conditions. For example, in the case of Grevelingen in round 1 of the decision-making process a very high score on the presence of cross-boundary informal networks compensates for low score on sense of urgency, trust and institutional arrangements. In round 2 of that same case we see that a high score on trust substitutes for lower scores on the other variables. Hence, not the same condition is every time important for playing its substituting role in different rounds of the decision-making process. Each round has its specific process-related characteristics making different conditions important for maintaining the level of vitality. This makes vitality an organic concept which cannot be developed or maintained mechanistically by choosing just one fixed (set of) condition(s) at all times.

The second relationship (i.e. mutual reinforcing relation among conditions) can be witnessed in both cases, but especially in the case of the Haringvliet Sluices as in the third round all conditions scored relatively positive (especially compared with the previous two rounds of decision-making). In this specific case we see a change with different persons being active in constructing boundary-crossing informal networking, which fuels constructive dialogue among actors in the social system and again this further catalyzes the development of trust. This influencing effect of boundary spanning work on dialogue development and trust building is also stressed in other literature (see: Van Meerkerk and Edelenbos, 2014).

The appearance of the two distinct relationships among conditions, i.e. the substituting and mutually reinforcing views, can be explained by the sudden increased development of vitality in a specific round of decision-making and also relates to the first conclusion in which we dealt with 'jumps in levels of vitality'. A combined relationship among conditions seems to be needed to realize significant increase in vitality of the social 
system in water governance practices. Singular improvements in conditions can be considered not to be decisive for realizing a big, significant increase in the level of vitality. This is specifically illustrated by the Haringvliet case. In this case the level of vitality was considerably low. Substantive efforts on all conditions were needed to realize an increase in the vitality of the social system. Despite the substantive increase in the scores of the conditions, the level of vitality is still moderate and certainly not that high as it is in the Grevelingen case. Hence, effort and results on all conditions are needed to realize 'jumps' in vitality levels. On the other hand conditions can substitute each other as the score of level of vitality is already high (8-10). It is then more about maintaining the level of vitality, in which one or two conditions can be used but not all are necessary. In the Grevelingen case we see for example that the level of vitality in the first round of decision-making is already high (score 8 ), but not all conditions have a necessary positive score; cross-boundary informal networking (to a high extent) and constructive dialogue (to a lesser extent) are sufficient for keeping vitality at a high level. This distinction between maintenance and development of vitality in relationship with conditions needs however more thought and scientific research, as it was not the explicit focus in our research.

From our study a couple of practical lessons learned for the governance of vitality in water governance processes can be formulated. One lesson learned is that much management effort has to be invested in drastically developing the vitality level in social systems. Actors have to invest all conditions to get social system vital. The other practical lesson learned is that once the social system has reached a reasonable level of vitality, this level can be maintained by strategic investment in one or two conditions. Management effort in starting up cross-boundary informal networking and trust-building seem crucial in this respect. However, simple measures cannot be given as social-ecological systems remain complex (highly unpredictable) by nature and need case and situation specific measurements in maintaining the level of vitality.

\section{References}

Adger, W.N., Brown K. and Tompkins, E.L. 2005. The political economy of cross-scale networks in resource co-management. Ecology and Society, 10(2), 9-20. [online] URL: http://www.ecologyandsociety.org/vol10/iss2/art9/

Ashmos, D.P., Duchon, D. and McDaniel, R.R. (2000). Organizational responses to complexity: The effect on organizational performance. Journal of Organizational Change, 13(6), 577 594.

Berkes, F., Folke, C. (Eds.), 1998. Linking Social and Ecological Systems: Management Practices and Social Mechanisms for Building Resilience. Cambridge University Press, Cambridge, UK.

Deakin, S., \& Wilkinson, F. (1998). Contract law and the economics of interorganizational trust. In C. Lane, \& R. Bachmann (Eds.), Trust within and between organizations (pp. 146172). Oxford, UK: Oxford University Press.

De Schipper, P. (2008). De Slag om de Oosterschelde. Amsterdam, Atlas.

Edelenbos, J., Steijn, A.J. \& Klijn, E.H. (2010). Does Democratic Anchorage Matter? An Inquiry Into the Relation Between Democratic Anchorage and Outcome of Dutch Environmental Projects. American Review of Public Administration, 40(1), 46-63. 
Edelenbos, J., N. Bressers, and P. Scholten (2013). Water Governance as Connective Capacity. London: Ashgate

Eshuis, J. \& Buuren, M.W. van (2013). Innovations in water governance: the importance of time. International Review of Administrative Sciences.

Faulkner, D., (1995), International strategic alliances, Mc Graw Hill Book company

Folke, C., Hahn, T., Olsson, P., Norberg, J., 2005. Adaptive governance of social-ecological systems. Annual Review of Environment and Resources 30, 441-473.

Foster-Fishman, P. G., Berkowitz, S. L., Lounsbury, D. W., Jacobson, S., \& Allen, N. (2001). Building collaborative capacity in community coalitions: a review and integrative framework. American Journal of Community Psychology, 29(2), 241-261.

Granovetter, M. (1973) The strength of weak ties. The American Journal of Sociology, 78(6): 1360-80.

Hansen, C.J. (2006), Urban transport, the environment and deliberative governance: the role of interdependence and trust, Journal of Environmental Policy and Planning, 8(2): 159179.

Healey, P. (1995). The institutional challenge for sustainable urban regeneration. Cities, 12(4), pp. 221-230.

Healey, P. (2006), Transforming governance: Challenges of institutional adaptation and a new politics of space, European Planning Studes, vol.14(3), 299-320.

Hodge, G. and C. Greve (2005), The Challenge of public private partnerships, Cheltenham: Edward Elgar

Holling, C.S., 1973. Resilience and stability of ecological systems. Annual Review of Ecology and Systematics 4, 1-23.

Horlings, I., P. Tops and V. Ostaaijen (2009). Regimes and vital coalitions in rural-urban regions in the Netherlands. Pp. 191-220 in K. Andersson, M. Lehtola, E. Eklund and P. Salmi eds, Beyond the rural-urban divide: cross-continental perspectives on the differentiated countryside and its regulation (Bingley: Emerald)

Huitema, D., E. Mostert, W. Egas, S. Moellenkamp, C. Pahl-Wostl, and R. Yalcin. (2009). Adaptive water governance: assessing the institutional prescriptions of adaptive (co-) management from a governance perspective and defining a research agenda. Ecology $\begin{array}{llllll}\text { and } & \text { Society } & 14 & (1): & 26 & \text { [online] }\end{array}$ http://www.ecologyandsociety.org/vol14/iss1/art26/.

Innes, J.E. and Booher, D.E. (2004). Reframing Public Participation: Strategies for the $21^{\text {st }}$ Century. Planning Theory \& Practice 5(4): 419-436.

Koppenjan JFM, Klijn E (2004) Managing uncertainties in networks: a network approach to problem solving and decision making. Routledge, London

Kotter, J.P. (2008), A sence of urgency, Harvard Business Press.

Klijn, E.H., J. Edelenbos, B. Steijn. 2010. Trust in governance networks; its impact and outcomes. Administration and Society, 42(2): 193-221.

Kuijken W (2010) Analyse uitvoering Besluit beheer Haringvlietsluizen. Samenvattende analyse en leerervaringen van de Deltacommissaris inzake het Besluit beheer 
Haringvlietsluizen, op verzoek van de Minister van V\&W, de Minister van LNV en Gedeputeerde Staten van Zuid-Holland

Lubell, M. and J. Edelenbos (2013). Integrated Water Resources Management: A Comparative Laboratory for Water Governance, International Journal of Water Governance, 1(3/4): 177-196.

March, J.G. and J.P. Olsen. 1989. Rediscovering Institutions. The Organizational Basis of Politics. New York: Free Press.

Nooteboom, B. (2002). Trust: Forms, foundations, functions, failures and figures. Cheltenham, UK: Edward Elgar.

Ostrom, E. 1998. The Institutional Analysis and Development Approach. In: LOEHMAN, E. T. \& KILGOUR, D. M. (eds.) Designing Institutions for Environmental and Resource Management. Cheltenham, UK: Edward Elgar

Pahl-Wostl, C. (2007). Transitions towards adaptive management of water facing climate and global change. Water Resour Manag, 21(1):49

Province South-Holland (2013). Program plan Integrative Programmaplan IRP GoereeOverflakkee.

Van Rooy, P., A. van Luin en E. Dil (2006). Netherland above water: regional development handbook, Gouda: Habiforum, Nirov, VROM.

RLG (2008). [Advisory Board rural area] Advice concerning the role of national government in fresh water supply for agriculture [in Dutch]. Publication RLG 08/04 March, 2008

Risse, T., and M. Kleine. (2007). Assessing the Legitimacy of the EU's Treaty Revision Methods. Journal of Common Market Studies, 45(1): 69-80.Rousseau, D., Sitkin, S. B., Burt, R. S., \& Camerer, C. (1998). Not so different after all: A cross discipline view of trust. The Academy of Management Review, 23, 393-404.

Sako, M. (1998). Does trust improve business performance? In C. Lane \&

R. Bachmann (Eds.), Trust within and between organizations: Conceptual issues and empirical applications (pp. 88-117). Oxford, UK: Oxford University Press.

Scharpf, F.W. (1997).Games Real Actors Play, Actor-Centered Institutionalism in Policy Research. Westview Press.

Scharpf, F.W. (1999). Governing in Europe: effective and democratic? Oxford University Press, Oxford.

Slager, K. (2010). Watersnood. Kats, De Buitenspelers.

Steijn, A.J., Klijn, E.H. \& Edelenbos, J. (2011). Public Private Partnerships: added value by organisational form or management? Public Administration, 89(4), 1235-1252.

Sullivan, H. \& Skelcher, C. (2002) Working Across Boundaries: Collaboration in Public Services (New York, NY: Palgrave/Macmillan).

Teisman, G.R. (2000). Models for research into decision-making processes: on phases, streams and decision-making rounds. Public Administration, 78(4), 937-956.

Teisman, G.R., Buuren, M.W., Gerrits, L.G. (2009). Managing Complex Governance Systems. Routledge, London

Thomas, G. (2011). A typology for the case study in social science following a review of definition, discourse and structure. Qualitative inquiry. 17 (6), 511-521.

Tushman, Michael L., and Thomas J. Scanlan. 1981. Boundary Spanning Individuals: Their Role in Information Transfer and Their Antecedents. The Academy of Management Journal, 24(2): 289-305. 
Van Meerkerk, I., Buuren, A. van, Edelenbos, J. (2013). Water managers' boundary judgments and adaptive water governance: An analysis of the Dutch Haringvliet sluices case. Water Resources Management, 27(7), 2179-2194.

Van Meerkerk, I., Edelenbos, J. (2014). The Effects of Boundary Spanners on Trust and Performance of Urban Governance Networks. Findings from Survey Research on Urban Development Projects in The Netherlands. Policy Sciences, 47(1): 3-24

Van Meerkerk, I., Edelenbos, J., Klijn, E.H. (2015). Connective Management and Governance Network Performance: the mediating role of Throughput Legitimacy - Environment and Planning C: Government and Policy (in press), DOI: 10.1068/c1345

Wagenaar H (2007) Governance, Complexity, and Democratic Participation: How Citizens and Public Officials Harness the Complexities of Neighborhood Decline. The American Review of Public Administration 37(1):17-50

Walker, B.H., Holling, C.S., Carpenter, S.R., Kinzig, A.P., 2004. Resilience, adaptability and transformability in social-ecological systems. Ecology and Society 9 (2), 5 [online] URL http://www. ecologyandsociety.org/vol9/iss2/art5/.

Weber, E.P., A. Memon and B. Painter (2011), Science, Society, and Water Resources in New Zealand: Recognizing and Overcoming a Societal Impasse, Journal of Environmental Policy and Planning, 13(1): 49-69.

Williams, Paul. 2002. The competent boundary spanner. Public Administration, 80: 103-124. Yin, R. (1984). Case study research: Design and methods (1st ed.). Beverly Hills, CA: Sage Publishing.

Zerubavel, E. (2003). Time maps. Chicago, The university of Chicago Press. 